\title{
Unemployed Persons in Border Municipalities of Northern Banat in Serbia
}

\author{
Pantelić Milana ${ }^{A *}$, Ivkov-Džigurski AnđelijaA, Ivanović LjubicaA, Dragin AleksandraA, Blešić Ivana ${ }^{A}$ \\ Received: November 2010 | Revised: December 2010 | Accepted: December 2010
}

\begin{abstract}
Border region of Northern Banat consists of three Banat municipalities. These municipalities are bordering with Romania and they occupy the ultimate eastern, peripheral position in Serbia. The number of inhabitants in border municipalities shows the declining tendency and a high unemployment rate is one of the causes of constant decline in the number of inhabitants. Halting of emigration process from the territories of border municipalities would contribute to stabilisation of their demographic status. This type of migratory processes can be efficiently affected through timely professional orientation. The problem of unemployment in the territories of border municipalities of Northern Banat could be regulated primarily with elaboration of a long-term plan. The results of the research, which was conducted in the period from January 2007 to December 2009, show that the number of unemployed persons was reduced in all border municipalities of Northern Banat at the end of the observed period compared to the beginning of 2007. Municipality of Coka has the largest percentage of unemployed persons in the total number of working-age population. Older categories with lower level of education dominate in the structure of unemployed persons.
\end{abstract}

Key words: Northern Banat, unemployment, border regions, demographic transition

\section{Introduction}

Border region of Northern Banat consists of three municipalities, and they are, going from the north to the south: Novi Knezevac, Coka, and Kikinda. These municipalities are bordering with Romania and occupy the surface of $1408 \mathrm{~km}^{2}$, or $\mathrm{I} 4.3 \%$ of the territory of Banat and almost $5.6 \%$ of the territory of Vojvodina. The largest area of $782 \mathrm{~km}^{2}$ belongs to Kikinda Municipality, and the smallest of 305 $\mathrm{km}^{2}$ to Municipality of Novi Knezevac (Statistical Office of the Republic of Serbia, 2004a).

Municipalities of Northern Banat make up the eastern half of Vojvodina Banat and they occupy the eastern, peripheral position in Vojvodina, which has become even more peripheral when Romania entered into the European Union (Ivkov et al., 20Io). Therefore, the geographical position of municipalities bordering with Romania is generally not favourable. In addition to accession of Romania into the European Union, placing of Serbia on the "White Schengen List" that reduced the rate of peripheralism of those municipalities was also
\end{abstract}

of great significance for the development of border municipalities of Northern Banat.

Population in border areas of Northern Banat records a constant downward trend, which is best illustrated by the results of the last Census from 2002. The analysis of the share of the population of border municipalities in the total population of Vojvodina also shows an evident decline (Statistical Office of the Republic of Serbia, 2004c). General characteristics of municipalities and settlements in border areas of Northern Banat are extremely unfavourable. They are characterised by depopulation, which is due to low population growth, age structure of the population, emigration processes and high unemployment rate (Vuksanovic et al, 2004). A large number of unemployed and low opportunities for job creation make only some in a series of problems that led to depopulation in the border areas of Northern Banat. A large number of rural settlements have been reduced in demographic sense (almost extinguished) due to fertile and working-age population drain (Nevenic, 2009).

\footnotetext{
A Department for Geography, Tourism and Hotel Management, Faculty of Science, University of Novi Sad; Trg Dositeja Obradovića 3; 21000 Novi Sad, Serbia

* Corresponding author: Milana Pantelic, e-mail: milana.pasic@dgt.uns.ac.rs
} 


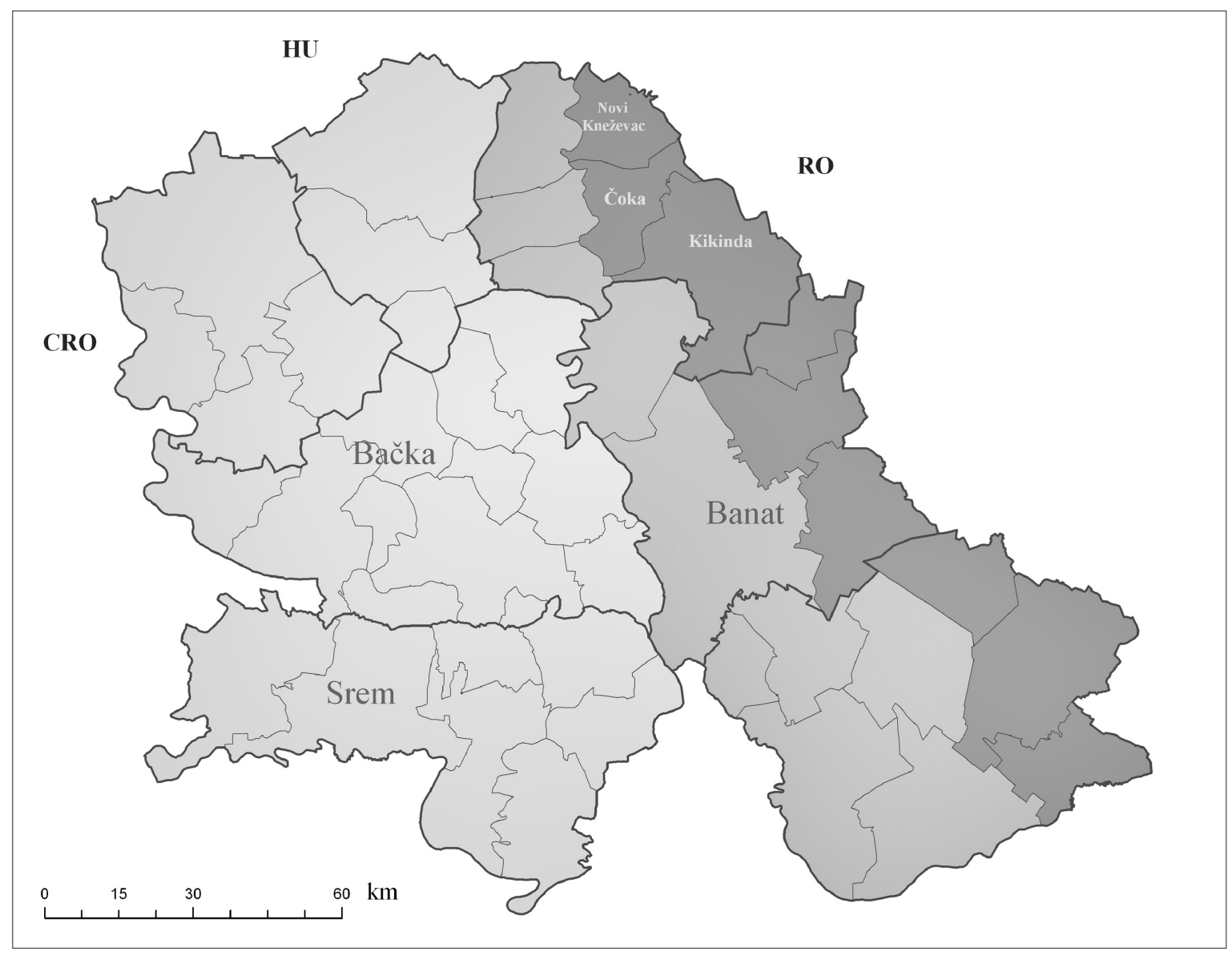

Figure 1. The position of Northern Banat municipalities in relation to the neighbouring countries

Depopulation processes and economic stagnation have resulted not only with socio-economic, but also with functional and physiognomy changes (Vujadinović, Gajic, 2008).

Lack of competitiveness at the market and small opportunities for export make one of the major reasons of high unemployment rate in the territory of Northern Banat.

Certain specific guidelines that would affect reduction of the number of unemployed persons in this area can be established based on the results of this study. The most vulnerable age and educational groups can also be determined so that special attention should be paid to them when creating and implementing specific regional programmes.

\section{Problems and consequences of long- term unemployment}

Unemployment is the problem that many countries have been faced with within the last ten years, and that is why this problem should not be addressed only by politicians but also by the society as a whole (Gomes, Gomes da Silva, 2009). Society and the state implement a variety of measures to mitigate this problem. Each measure that is carried out has got both the advantages and disadvantages. A long temporal span that exists be- tween the implemented measures and expected results further hinders the combat against depopulation. Decision-makers when it comes to such measures are the politicians, whose mandate is usually shorter than the time it takes for the measure to show the results. Therefore, they avoid advocating investments implying large financial resources, which will prove justified only after 20-25 years (Djurdjev, 2006).

The evidences confirming this fact are many studies that have been conducted in countries around the world. The research conducted in Argentina showed that in the last decade, the unemployment rate had increased significantly (Galiano, Hopenhayn, 2003). There are also examples of South African countries showing that their residents are exposed to poverty and great social problems, because of a large number of unemployed individuals (Kingdon, Knight, 2006). The research conducted in the U.S. (Mukoyama, Sahin, 2009) and Holland (Dur, 200I) show that duration of unemployment in the last 30 years is getting longer and longer.

Long-term unemployment can have very negative consequences that also affect the capacities of workers. In time, an unemployed individual loses his/her skills or his/her work skills and work experience are becoming outdated (Van Ours, Vo- 
dopivec, 2008). The survey conducted in Ukraine in the period from 1998-2002 showed that negative effects of unemployment were largely manifested after I4 months of unemployment $(\mathrm{Ku}-$ pets, 2006). A large percentage of unemployment should cause serious concern because it affects disruption of economic prosperity, reduction of industrial production, reduction of human capital, leads to increased crime, and causes social instability (Kingdon, Knight, 2004).

Unemployment and migrations of the population are contemporary economic-geographic and social phenomena. Unemployment as negative phenomenon is longer in its existence and has deeper causes and consequences of economic and social character (Cvoro, I982). There are many consequences of long-term unemployment that affect mental and physical condition of an individual (Ezzy, 1993). The results of many studies worldwide show that long-term unemployment also causes health problems, and that employed individuals are with significantly less mental disorders in relation to unemployed individuals (Graetz, I993, Kivimaki et al, 2003). Researches also show that psychological disorders are manifested to a higher extent among unemployed women (Hammarström, I996). Case studies, which examine the connections between unemployment and suicide attempts show how serious unemployment is a psychological problem (Fergusson et al, 2007), and they confirm that a large percentage of those who attempt suicide are unemployed individuals. One of the researches that has confirmed this fact was carried out in Italy during the period from I977 to I987 (Platt et al, I992). The research conducted in Taiwan during the period from 1959 to 2007 showed that such cases were more pronounced among the unemployed male population (Chang et al, 20IO).

There are several possibilities for revitalisation of areas affected by depopulation. Depopulation could be prevented by keeping the young population (Ivkov et al, 2007), in particular in rural areas, by providing young people jobs and creating of conditions for quality life and better and more certain future. Stimulating and developing of ecoand ethno-tourism would provide an opportunity for opening of new jobs. Rural areas have favourable conditions for this kind of tourism, and they are reflected primarily in the preserved nature, unpolluted air and abundance of vegetation (Pavlovic, Jovanovic, 2009). Different support programmes that have a stimulating role to activate unemployed individuals and assist them in seeking new jobs are of great significance (Brown et al, 2008, Boeri, Macis, 2009). An interesting research was conducted in Sweden, and it showed that unemployed persons who received pecuniary benefit were more active in looking for new employment during the period that was close to expiry of that type of assistance (Carling et al, 1996).

In Serbia, the National Employment Service (NES) offers each year a variety of programmes such as the disabled employment programmes, self-employment programmes, regional programmes, programmes of professional training of interns, volunteers and practitioners, programmes exempting the employers from paying a portion of contributions for those aged more than 45 or 50, education for the establishment and running of small businesses, education for active job search, organising of courses in computer science, foreign languages, accounting ... (NES Kikinda, 2009). The implementation of these programmes could greatly reduce the percentage of unemployment in the border municipalities of Banat.

\section{Research methodology}

Monitoring and assessment of the number of unemployed persons in the border area of Northern Banat was conducted in the period of three years. The research analyses the period from January 2007 until December 2009, in the municipalities of Novi Knezevac, Coka, and Kikinda. The research included all working and individuals capable of working. The data were taken over from the National Employment Service, and they were summarised and statistically processed. The study that included nine border municipalities of Banat was conducted in the period 2007/2008, so that the results of that study were compared with the above-mentioned data.

The basic methods used in collecting and processing of data and analysis of the obtained results included historical method (written documentation, statistical data, research of the results on related topics), statistical processing of the studied references and other material, quantitative and qualitative content analysis, and comparative method.

Pursuant to the Law on Employment and Unemployment Insurance (Official Gazette of the Republic of Serbia, no. 7I/03), an unemployed person is any person aged 15 to 65 years, capable and ready to work immediately, who has not been employed, or otherwise exercised the right to work, and who is being registered as unemployed and actively seeking employment (National Employment Service Kikinda, 2009).

\section{Analysis of the results and discussion}

According to the latest Census, the largest percentage of the population of Vojvodina is involved in manufacturing $(26.1 \%, 29.3 \%$ in cities), agriculture $(22.6 \%, 8.3 \%$ in cities), while the third place 
belongs to trade; repair of motor vehicles, motorcycles, and items for and personal and household goods (I2.9\%, $15.9 \%$ in cities).

\section{The structure of employed individuals in the municipality of Novi Knezevac}

In the municipality of Novi Knezevac the population deals dominantly with agriculture and the share of such population in the municipality is $39.2 \%$, while it is much lower in the town of New Knezevac itself, i.e. agriculture takes the second place with $17.2 \%$. The second place according to the share in the municipality belongs to manufacturing $(23.2 \%)$, while it takes the first place in the town itself with $32.3 \%$. The third place in both the municipality (9.1\%) and in the town (I2.I\%) belongs to trade, with the accompanying contents (Statistical Office of the Republic of Serbia, 2004b). Comparing these data with the data from other smaller border municipalities, such as Nova Gradiska, Zitiste, Secanj, Plandiste and Bela Crkva (Pasic et al., 20Io), we see no major differences because the majority of the population deals are employed in agriculture, manufacturing and trade.

\section{The structure of unemployed persons in the municipality of Novi Knezevac according to age and gender}

As of December 3I $\mathrm{I}^{\mathrm{st}}, 2009$, there were I,II9 unemployed persons in the municipality of Novi Knezevac, which made about $14.9 \%$ of the working age population of the municipality. Compared to municipalities of Coka and Kikinda, as well as to other municipalities in the border part of Banat ( $\mathrm{Pa}$ sic et al., 20I0), the municipality of Novi Knezevac has the lowest share of unemployed working-age population. The percentage differences are not large, but they indicate that municipality of Novi Knezevac is one of economically most developed municipalities in this part of Banat.

The difference between the actual and presented number is the result of several elements, because a person is deleted from the Register of this Service based on different reasons:

I. If he/she fails to report regularly to the National Employment Service

2. If he/she fails to reply to the officials calls of the National Employment Service

3. If he/she fails to report to the employer to whom he/she is sent for an interview

4. If he/she refuses a job without a justified reason

5. If he/she is dealing with business activities that are not entirely legal and are not registered (National Employment Service Kikinda, 2009).

Age structure is very important for demographic development of an area since it shows us not only the previous development and the current state, but also enables us to predict the future trends in the population numbers (Mijanović, 2008).

If we analyse the data on unemployed persons according gender and age (Table I) we notice that there are $58 \%$ of men and $42 \%$ of women out of the total number of unemployed.

Persons in the age groups 45-49 (I4.9\%), 40-44 (I4.I\%), and 30-34 (I3.4\%) dominate in the structure according to age.

If we analyse men and women separately, it is evident that the highest share of unemployed among both men and women is in the age group of $45-49$ ( $14.0 \%$ men and $16.1 \%$ in women), followed by categories of 50-54 (13.9\%) for men and category of 40-44 (15.7\%) for women.

We can see that there is the difference between the municipality of Coka and Kikinda where the highest percentage of unemployed women are aged 35-39, while in the municipality of Novi Knezevac they are aged 45-49. In addition to that, a higher percentage of unemployed women in the age group of 35-39 dominate in the structure in other border municipalities of Banat (Ivkov et al., 2010).

The smallest share in the total number of unemployed persons belongs to persons than 60 and older (I.8\%), as well as to persons under the age of $20(3.2 \%)$, because most of them are still in the education process.

\section{The structure of unemployed persons in the municipality of Novi Knezevac according to gender and education}

According to the data as of December $3 \mathrm{I}^{\text {st }}, 2009$, almost a half of unemployed persons in the municipality of Novi Knezevac (Table 2) are with the level I of education (46\%), followed by level III (23\%) and level IV (20.8\%).

Table 1. Unemployed persons according to gender and age in the municipality of Novi Knezevac

\begin{tabular}{|c|r|r|r|r|r|r|}
\hline & \multicolumn{2}{|c|}{ Total } & \multicolumn{2}{|c|}{ Male } & \multicolumn{2}{c|}{ Female } \\
\cline { 2 - 7 } & Number & \multicolumn{1}{c|}{$\%$} & Number & \multicolumn{1}{c|}{$\%$} & Number & \multicolumn{1}{c|}{$\%$} \\
\hline Total & 1,119 & 100 & 648 & 100 & 471 & 100 \\
\hline $15-19$ year & 36 & 3.2 & 19 & 2.9 & 17 & 3.6 \\
\hline $20-24$ & 115 & 10.3 & 63 & 9.7 & 52 & 11.0 \\
\hline $25-29$ & 134 & 12.0 & 86 & 13.3 & 48 & 10.2 \\
\hline $30-34$ & 150 & 13.4 & 79 & 12.2 & 71 & 15.1 \\
\hline $35-39$ & 129 & 11.5 & 71 & 11.0 & 58 & 12.3 \\
\hline $40-44$ & 158 & 14.1 & 84 & 13.0 & 74 & 15.7 \\
\hline $45-49$ & 167 & 14.9 & 91 & 14.0 & 76 & 16.1 \\
\hline $50-54$ & 143 & 12.8 & 90 & 13.9 & 53 & 11.3 \\
\hline $55-59$ & 67 & 6.0 & 45 & 6.9 & 22 & 4.7 \\
\hline $60-64$ & 20 & 1.8 & 20 & 3.1 & 0 & 0.0 \\
\hline $65+$ & 0 & 0.0 & 0 & 0.0 & 0 & 0.0 \\
\hline
\end{tabular}

Source: National Employment Service, Kikinda. Status as of December 31 ${ }^{\text {st }}, 2009$ 
The situation is highly disadvantageous, since, as it can be seen, $5 \mathrm{I} .3 \%$ of unemployed persons are unskilled persons, and about $44 \%$ are persons with a lower level of skills (levels III and IV).

A positive fact is that the share of unemployed persons with higher levels of skills, i.e. levels from VI-I to VIII, is small (somewhat less than $4.7 \%$ ).

Compared to other municipalities that are located in the border part of Northern Banat, as well as to other neighbouring municipalities (lvkov et al., 20Io), we see that municipality of Novi Knezevac has the highest percentage of unemployed persons with the education level I.

If we look at the gender ratio, we can see that the largest share of unemployed men is with the education level I (47.2\%), followed by women with the same level of education (44.4\%). The next largest category are men that have completed level III of education (27.3\%), and women who have completed level IV of education (28.9\%).

The analysis of the number of unemployed in the municipality of Novi Knezevac covering the period from January 2007 to December 2009 (Figure 2), shows the following situation: The rates of unemployed is gradually decreasing from January to August 2007; from August 2007 to July 2008 , the rates of unemployed is relatively consistent with a gradual increase; in July 2008, the rates of unemployed persons decreased significantly and it reached its minimum in September (I4.I\%); from September 2008, the rates of unemployed gradually increased, and in July 2009 there

Table 2. Unemployed persons according to the education level* and gender in the municipality of Novi Knezevac

\begin{tabular}{|l|r|r|r|r|r|r|}
\hline & \multicolumn{2}{|c|}{ Total } & \multicolumn{2}{|c|}{ Male } & \multicolumn{2}{c|}{ Female } \\
\cline { 2 - 7 } & Number & \multicolumn{1}{|c|}{$\%$} & Number & \multicolumn{1}{c|}{$\%$} & Number & \multicolumn{1}{c|}{$\%$} \\
\hline I level & 515 & 46.0 & 306 & 47.2 & 209 & 44.4 \\
\hline II level & 59 & 5.3 & 41 & 6.3 & 18 & 3.8 \\
\hline III level & 257 & 23.0 & 177 & 27.3 & 80 & 17.0 \\
\hline IV level & 233 & 20.8 & 97 & 15.0 & 136 & 28.9 \\
\hline V level & 2 & 0.2 & 2 & 0.3 & 0 & 0.0 \\
\hline VI-1 level & 26 & 2.3 & 12 & 1.9 & 14 & 3.0 \\
\hline VI-2 level & 2 & 0.2 & 1 & 0.2 & 1 & 0.2 \\
\hline VII-1 level & 25 & 2.2 & 12 & 1.9 & 13 & 2.8 \\
\hline VII-2 level & 0 & 0.0 & 0 & 0.0 & 0 & 0.0 \\
\hline VIII level & 0 & 0.0 & 0 & 0.0 & 0 & 0.0 \\
\hline Unqualified [I+II] & 574 & 51.3 & 347 & 53.5 & 227 & 48.2 \\
\hline Qualified [III-VIII] & 545 & 48.7 & 301 & 46.5 & 244 & 51.8 \\
\hline Total & 1,119 & 100 & 648 & 100 & 471 & 100 \\
\hline
\end{tabular}

Source: National Employment Service, Kikinda. Status as of December 31st, 2009 .

* Level I - elementary school; level IV - four grades of secondary school; level VI - completed higher school; level VII - university graduates [faculty]; level VIII - PhD degree was a significant increase in the rates of unemployed, reaching its maximum of $19.2 \%$; since July 2009 , the rates of unemployed persons in gradually declining, and at the end of the observed period, there were $14.9 \%$ unemployed persons. Based on the above, we see that the number of unemployed at the end of the observed period was about 2.5\% lower than in January 2007. Regretfully, the reason that explains the reduction in the number of unemployed people is not opening of new jobs, but deletion of unemployed persons from the Register because of irregular reporting to the Service, or based on their own will.

\section{The structure of employed persons in the municipality of Coka}

The population dealing with agriculture dominates in the structure of employed persons in the municipality of Coka with the share of $48.4 \%$, while it takes the second place in the town of Coka with the share of somewhat less than $26.8 \%$. The second place according to the share in the municipality belongs to population that is employed in the manufacturing sector (2I.2\%), while in the town of Coka it takes the first place with the share of $31.5 \%$. The third place in both the municipality (6.6\%) and the town (7.0\%) belongs to trade, with accompanying activities and public administration and compulsory social security (in the town with the share of $7.0 \%$ ) (Statistical Office of the Republic of Serbia, 2004b).

\section{The structure of unemployed persons in the municipality of Coka according age and gender}

As of December $3 \mathrm{I}^{\text {st }}, 2009$, there were I,24I unemployed persons in the municipality of Coka, which makes about $16 \%$ of the working population of the municipality. Compared to municipalities in the central and southern border part of Banat (lvkov et al., 2010), we see that the municipality of Coka, as well as other two municipalities of the border part of Northern Banat has a much smaller share of unemployed population.

Due to various reasons and deleting people from the Register of the National Employment Service, the percentage of unemployed persons may be even higher.

If we analyse the data on unemployed persons according to gender and age (Table 3 ) we can notice that there are $54.2 \%$ of men and $45.8 \%$ of women in the total number of unemployed.

The age groups from $45-49$ (I4.7\%), 40-44 (I2.8\%) and $25-29$ (I2.5\%) dominate in the structure according to age. As in most border municipalities, we notice a large share of older unemployed persons.

If we analyse men and women separately, it is evident that the highest share of unemployed 


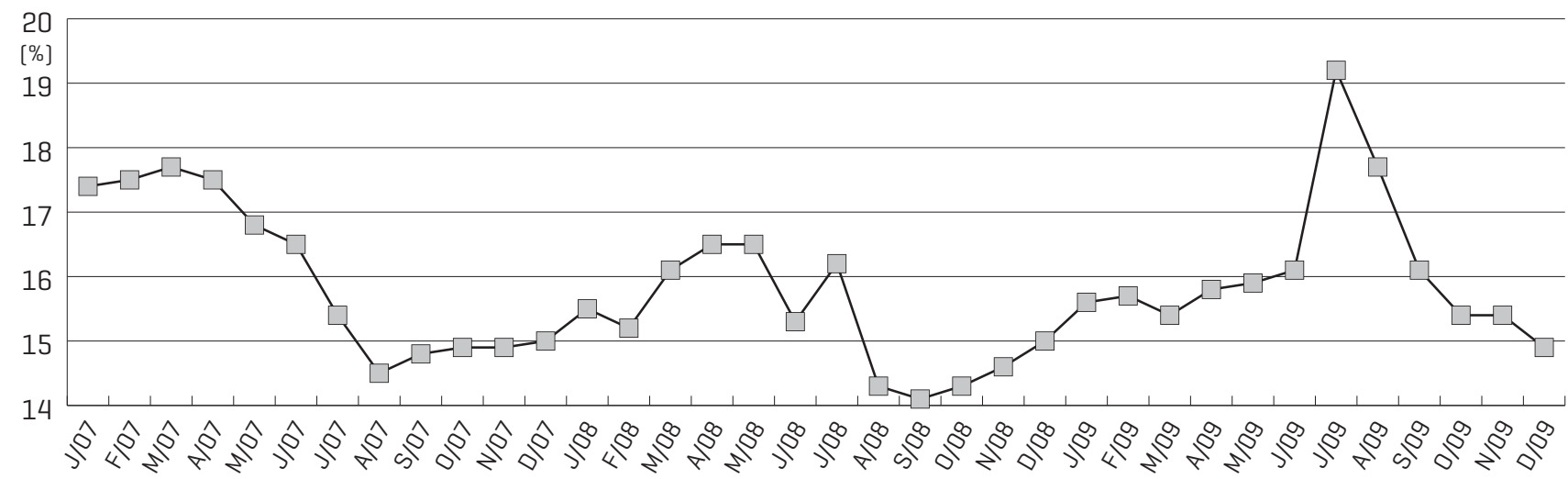

Figure 2. Rates of unemployed in the municipality of Novi Knezevac in the period from January 2007 to December 2009. Source: National Employment Service, Kikinda. Status in the period from January 2007 to December 2009.

among men is in the age group of $45-49$ ( $15.8 \%$ ). The data show that $55 \%$ of unemployed men in the municipality are 40 and older.

The highest percentage among unemployed women belongs to the age group of 35-39 (13.9\%).

The smallest share in the total number of unemployed persons belongs to persons 60 and older $(2.3 \%)$, as well as persons under the age of $20(6.0 \%)$.

\section{The structure of unemployed persons in the municipality of Coka according to gender and education}

According to the data as of December $3 \mathrm{I}^{\text {st }}, 2009$, the highest share of unemployed persons in municipality of Coka (Table 4) are with the level I of education (43.9\%), followed by level III (26.3\%) and level IV (22.6\%). This is not good because a large percentage of unemployed (47.8\%) are unskilled persons, and $48.9 \%$ are persons with a lower level of education (III and IV), which makes the situation highly unfavourable. A positive fact is that the share of unemployed persons with higher levels of skills, i.e. levels from V to VIll, is exceptionally small, only $3.2 \%$. In relation to the municipalities of Novi Knezevac and Kikinda, the municipality has the lowest share of highly educated unemployed population. Compared to municipalities in the central and southern border part of Banat (Ivkov et al., 20Io), we see that the municipality of Coka, has the lowest percentage of unemployed persons with university education.

The results show that older population with lower level of education dominates in the structure of unemployed, and it is the group for which it is generally the most difficult to find employment. If we look at the gender ratio, we can see that the largest share of unemployed men is with the education level I (45.3\%), followed by women with the same level of education (42.3\%). The next largest category are men that have completed level IIl of education (30.3\%), and women who have completed level IV of education (29.0\%).
Table 3. Unemployed persons according to gender and age in the municipality of Coka

\begin{tabular}{|c|r|r|r|r|r|r|}
\hline & \multicolumn{2}{|c|}{ Total } & \multicolumn{2}{|c|}{ Male } & \multicolumn{2}{c|}{ Female } \\
\cline { 2 - 7 } & Number & \multicolumn{1}{|c|}{$\%$} & Number & \multicolumn{1}{c|}{$\%$} & Number & \multicolumn{1}{c|}{$\%$} \\
\hline Total & 1,241 & 100 & 673 & 100 & 568 & 100 \\
\hline $15-19$ year & 75 & 6.0 & 45 & 6.7 & 30 & 5.3 \\
\hline $20-24$ & 142 & 11.4 & 73 & 10.8 & 69 & 12.1 \\
\hline $25-29$ & 155 & 12.5 & 80 & 11.9 & 75 & 13.2 \\
\hline $30-34$ & 137 & 11.0 & 51 & 7.6 & 86 & 15.1 \\
\hline $35-39$ & 133 & 10.7 & 54 & 8.0 & 79 & 13.9 \\
\hline $40-44$ & 159 & 12.8 & 86 & 12.8 & 73 & 12.9 \\
\hline $45-49$ & 183 & 14.7 & 106 & 15.8 & 77 & 13.6 \\
\hline $50-54$ & 148 & 11.9 & 86 & 12.8 & 62 & 10.9 \\
\hline $55-59$ & 81 & 6.5 & 64 & 9.5 & 17 & 3.0 \\
\hline $60-64$ & 28 & 2.3 & 28 & 4.2 & 0 & 0.0 \\
\hline $65+$ & 0 & 0.0 & 0 & 0.0 & 0 & 0.0 \\
\hline
\end{tabular}

Source: National Employment Service, Kikinda. Status as of December 31st, 2009.

Table 4. Unemployed persons according to the education level and gender in the municipality of Coka

\begin{tabular}{|l|r|r|r|r|r|r|}
\hline & \multicolumn{2}{|c|}{ Total } & \multicolumn{2}{c|}{ Male } & \multicolumn{2}{c|}{ Female } \\
\cline { 2 - 7 } & Number & \multicolumn{1}{|c|}{$\%$} & Number & $\%$ & Number & \multicolumn{1}{c|}{$\%$} \\
\hline I level & 545 & 43.9 & 305 & 45.3 & 240 & 42.3 \\
\hline II level & 48 & 3.9 & 29 & 4.3 & 19 & 3.3 \\
\hline III level & 327 & 26.3 & 204 & 30.3 & 123 & 21.7 \\
\hline IV level & 281 & 22.6 & 116 & 17.2 & 165 & 29.0 \\
\hline V level & 3 & 0.2 & 3 & 0.4 & 0 & 0.0 \\
\hline VI-1 level & 19 & 1.5 & 8 & 1.2 & 11 & 1.9 \\
\hline VI-2 level & 2 & 0.2 & 2 & 0.3 & 0 & 0.0 \\
\hline VII-1 level & 16 & 1.3 & 6 & 0.9 & 10 & 1.8 \\
\hline VII-2 leveI & 0 & 0.0 & 0 & 0.0 & 0 & 0.0 \\
\hline VIII level & 0 & 0.0 & 0 & 0.0 & 0 & 0.0 \\
\hline Unqualified [I+II] & 593 & 47.8 & 334 & 49.6 & 259 & 45.6 \\
\hline Qualified [III-VIII] & 648 & 52.2 & 339 & 50.4 & 309 & 54.4 \\
\hline Total & 1,241 & 100 & 673 & 100 & 568 & 100 \\
\hline
\end{tabular}

Source: National Employment Service, Kikinda. Status as of December 31²t, 2009 


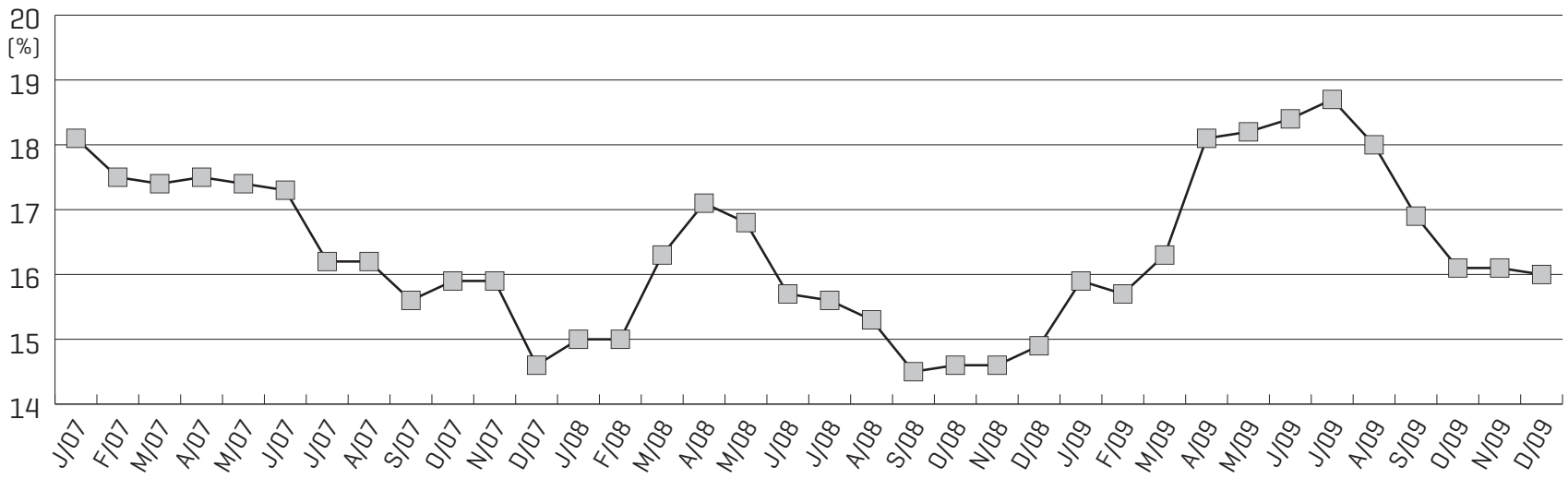

Figure 3. Rates of unemployed in the municipality of Coka in the period from January 2007 to December 2009 Source: National Employment Service, Kikinda. Status in the period from January 2007 to December 2009.

The analysis of the number of unemployed in the municipality of Coka covering the period from January 2007 to December 2009 (Figure 3), shows the following situation: The number of unemployed is gradually decreasing from January to December 2007; from December 2007 to April 2008 , the number of unemployed is relatively consistent with a gradual increase; after that the number continued to decline and it reached its minimum in September 2008 (I4.5\%); from September 2008 , the rates of unemployed increased, and in July 2009 there was a significant increase in the rates of unemployed, reaching its maximum of $18.7 \%$; since July 2009 , the rates of unemployed persons in gradually declining, and at the end of the observed period, there were $16.0 \%$. Based on the above, we see that the number of unemployed at the end of the said period was about 2.I\% lower than in January 2007.

\section{The structure of employed persons in the municipality of Kikinda}

The population involved in manufacturing sector dominates in the structure of employed persons in the municipality of Kikinda (33.5\%), while the percentage is even higher in the town of Kikinda (37.4\%). The second place according to the share in the municipality belongs to population dealing with agriculture (I8.I\%), while in the town of Kikinda the second place belongs to trade; repair of motor vehicles, motorcycles, and items for and personal and household goods with $\mathrm{I} 2.8 \%$. The third place in the municipality belongs to trade with the accompanying activities (I0.9\%), while in the town of Kikinda the third place belongs to agriculture with $7.9 \%$. (Statistical Office of the Republic of Serbia, 2004b). The results show slight differences compared to other two studied municipalities as well as compared to other border municipalities in Banat since the majority population is employed in the manufacturing sector and not in agriculture. A larger percentage of the employed in the manufacturing sector is also registered in the municipality of Vrsac (Pasic, et al., 20I0). Based on that we can conclude that larger municipalities, such as Kikinda and Vrsac, dispose with more developed manufacturing sector.

\section{The structure of unemployed persons in the municipality of Kikinda according age and gender}

As of December $3 \mathrm{I}^{\text {st }}, 2009$, there were 6,397 unemployed persons in the municipality of Kikinda, which makes about $15.7 \%$ of the working population of the municipality.

The difference between the actual and presented number of unemployed persons is the consequence of several elements, primarily of deleting people from the Register of the National Employment Service.

If we analyse the data on unemployed persons according to gender and age (Table 5) we can notice that there are $49.3 \%$ of men and $50.7 \%$ of women in the total number of unemployed. Compared to the previous two municipalities, the percentage of unemployed female population is somewhat higher in the municipality of Kikinda, while in the municipalities of Novi Knezevac and Coka the unemployed male population dominates. Among other municipalities in the border part of Banat (Ivkov, et al., 20IO) we can single out the municipality of Vrsac, which also has somewhat higher percentage of unemployed women compared to men. Based on those data we can conclude that in larger municipalities, such as Kikinda and Vrsac, there are more opportunities for employment of female population.

The age groups from $25-29$ (12.8\%), 35-39 (I2.7\%) and 50-54 (I2.4\%) dominate in the structure according to age. This is not an encouraging data since it is known that employers employ older individuals less frequently and there are more than $70 \%$ of unemployed persons in the municipality of Kikinda who are older than 30. 
If we analyse men and women separately, it is evident that the highest share of unemployed among men is in the age group of $20-24$ (30.6\%) and 25-29 (I2.7\%). The data show significant difference compared to municipalities of Novi Knezevac and Coka since persons aged 45-49 dominate in the structure of unemployed men in those two municipalities. In other border municipalities pf Banat (Ivkov, et al., 20Io) older age groups of unemployed men also dominate in the structure, which is best shown by the example of municipality of Bela Crkva with more than 30\% of unemployed men older than 45 .

The highest percentage among unemployed women belongs to the age group of $35-39$ (I4.9\%) and 30-34 (13.6\%).

The smallest share in the total number of unemployed persons belongs to persons 60 and older $(2.7 \%)$, as well as persons under the age of $20(4.2 \%)$.

\section{The structure of unemployed persons in the municipality of Kikinda according to gender and education}

According to the data as of December $3 \mathrm{I}^{\text {st }}, 2009$, the highest share of unemployed persons in municipality of Coka (Table 6) are with the level I of education (42.3\%), followed by level III (25.3\%) and level IV (2I.5\%).

The situation cannot be characterised as favourable since, as we see, $47 \%$ of unemployed are unskilled persons and about $47 \%$ are persons with lower level of education (III and IV).

The share of unemployed persons with higher education levels from V to VIII is also significant. Compared to other border municipalities of Banat (Ivkov et al., 20Io), the municipality of Kikinda singles out as the municipality with the highest share of unemployed persons with high (university) education (6\%). In addition to municipality of Kikinda, the municipality of Vrsac also records a significant percentage of unemployed persons with high (university) education (lvkov et al., 20I0). Based on the above we can conclude that it is more difficult for persons with high (university) education to find employment in larger municipalities. In the municipalities with over 30,000 inhabitants there is a greater demand for employees, there are more job openings, however the competition of young highly educated work force is up to ten times greater than in smaller municipalties.

If we look at the gender ratio, we can see that the largest share of unemployed men is with the education level I (42.8\%), followed by women with the same level of education (4I.8\%). The next largest category are men that have completed level III of education (30.1\%), and women who have completed level IV of education (26.9\%). We can see
Table 5. Unemployed persons according to gender and age in the municipality of Kikinda

\begin{tabular}{|c|r|r|r|r|r|r|}
\hline \multirow{2}{*}{ Total } & \multicolumn{2}{|c|}{ Total } & \multicolumn{2}{|c|}{ Male } & \multicolumn{2}{c|}{ Female } \\
\cline { 2 - 7 } & Number & \multicolumn{1}{c|}{$\%$} & Number & \multicolumn{1}{c|}{$\%$} & Number & \multicolumn{1}{c|}{$\%$} \\
\hline $15-19$ year & 266 & 100 & 3,155 & 100 & 3,242 & 100 \\
\hline $20-24$ & 744 & 11.6 & 406 & 12.9 & 338 & 10.4 \\
\hline $25-29$ & 817 & 12.8 & 401 & 12.7 & 416 & 12.8 \\
\hline $30-34$ & 795 & 12.4 & 353 & 11.2 & 442 & 13.6 \\
\hline $35-39$ & 812 & 12.7 & 330 & 10.5 & 482 & 14.9 \\
\hline $40-44$ & 767 & 12.0 & 355 & 11.3 & 412 & 12.7 \\
\hline $45-49$ & 733 & 11.5 & 326 & 10.3 & 407 & 12.6 \\
\hline $50-54$ & 795 & 12.4 & 386 & 12.2 & 409 & 12.6 \\
\hline $55-59$ & 497 & 7.8 & 283 & 9.0 & 214 & 6.6 \\
\hline $60-64$ & 170 & 2.7 & 159 & 5.0 & 11 & 0.3 \\
\hline $65+$ & 1 & 0.0 & 1 & 0.0 & 0 & 0.0 \\
\hline
\end{tabular}

Source: National Employment Service, Kikinda. Status as of December 315t, 2009.

that are no significant differences compared to the data for municipalities of Novi Knezevac and Coka since the same categories of unemployed persons dominate in the structure of unemployed in the municipality of Kikinda. There are also no differences compared to other municipalities in the border region of Banat.

The analysis of the rates of unemployed in the municipality of Kikinda covering the period from January 2007 to December 2009 (Figure 4), shows the following situation: The rates of unemployed in the period from January 2007 to December 2009 varies and the highest rates of unemployed was registered in March 2007; from

Table 6. Unemployed persons according to the education level, age and gender in the municipality of Kikinda

\begin{tabular}{|l|r|r|r|r|r|r|}
\hline \multirow{2}{*}{} & \multicolumn{2}{|c|}{ Total } & \multicolumn{2}{c|}{ Male } & \multicolumn{2}{c|}{ Female } \\
\cline { 2 - 7 } & Number & \multicolumn{1}{c|}{$\%$} & Number & \multicolumn{1}{c|}{$\%$} & Number & \multicolumn{1}{c|}{$\%$} \\
\hline I level & 6,273 & 42.3 & 3,272 & 42.8 & 3,001 & 41.8 \\
\hline II level & 744 & 5.0 & 416 & 5.4 & 328 & 4.6 \\
\hline III level & 3,759 & 25.3 & 2,307 & 30.1 & 1,452 & 20.2 \\
\hline IV level & 3,190 & 21.5 & 1,255 & 16.4 & 1,935 & 26.9 \\
\hline V level & 101 & 0.7 & 81 & 1.1 & 20 & 0.3 \\
\hline VI-1 level & 377 & 2.5 & 149 & 1.9 & 228 & 3.2 \\
\hline VI-2 level & 52 & 0.4 & 17 & 0.2 & 35 & 0.5 \\
\hline VII-1 level & 339 & 2.3 & 152 & 2.0 & 187 & 2.6 \\
\hline VII-2 level & 4 & 0.0 & 3 & 0.0 & 1 & 0.0 \\
\hline VIII level & 1 & 0.0 & 1 & 0.0 & 0 & 0.0 \\
\hline Unqualified [I+II] & 7,017 & 47.3 & 3,688 & 48.2 & 3,329 & 46.4 \\
\hline Qualified [III-VIII] & 7,823 & 52.7 & 3,965 & 51.8 & 3,858 & 53.6 \\
\hline Total & 14,840 & 100 & 7,653 & 100 & 7,187 & 100 \\
\hline
\end{tabular}

Source: National Employment Service, Kikinda. Status as of December 31st, 2009. 


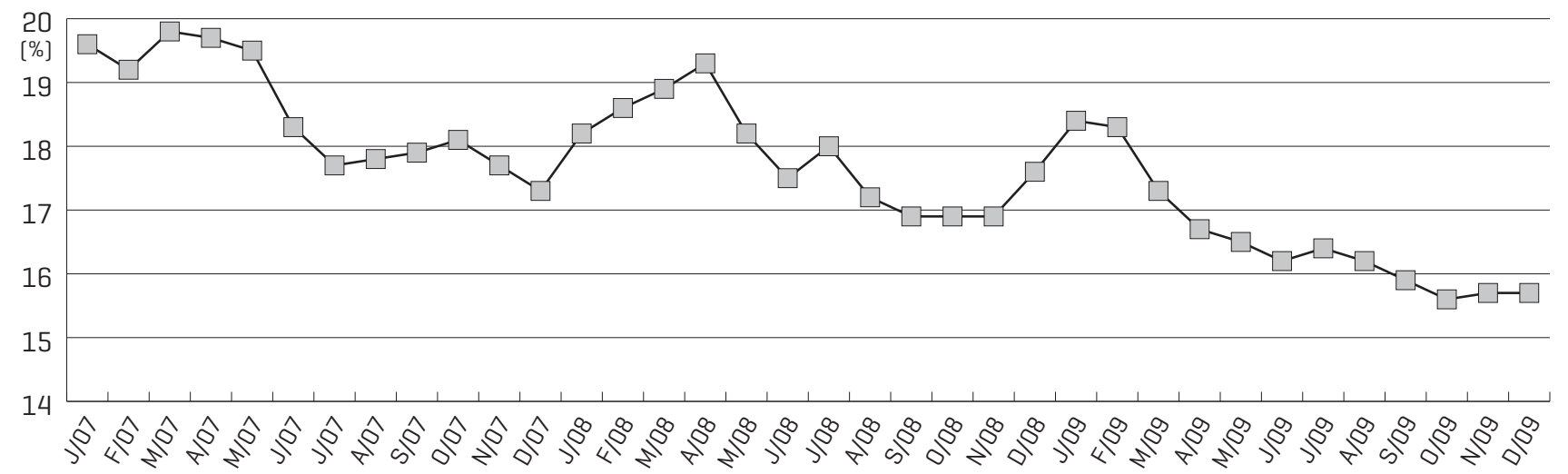

Figure 4. Rates of unemployed in the municipality of Kikinda in the period from January 2007 to December 2009 Source: National Employment Service, Kikinda. Status in the period from January 2007 to December 2009

March to December 2007 the rates of unemployed was declining; the rates of unemployed persons declined in that period largely due to the fact that the law pursuant to which the unemployed persons do not need to be registered with the National Employment Service in order to be entitled to social security was enacted by the beginning of 2007; a large number of individuals were deleted from the Register based on their free will although they were unemployed; the number of unemployed persons starting increasing by the beginning of 2008 and that trend continued until April 2008 when it started declining again. In the beginning of 2008 , several large enterprises were privates in the municipality of Kikinda, which resulted with the increase of the number of unemployed persons due to a large number of people who were left jobless. In the period from April 2008 to November 2008, the rates of unemployed persons was declining. After that, there was a slight increase in number that lasted until January 2009. Since January 2009 , the rates of unemployed persons in the municipality of Kikinda has been declining constantly, only to reach its minimum in October 2009 (15.6\%). At the end of the observed period, there were $15.7 \%$ unemployed persons, which is about $3.9 \%$ persons less than in January 2007 .

Privatisation processes in the municipality of Kikinda were the most extensive at the beginning of 2008. In smaller municipalities, such as Coka and Novi Knezevac, a more intensive privatisation and termination of certain factories occurred in the mid of 2009, which is why in these municipalities in the aforementioned period the greatest level of unemployment occurred. The high unemployment rate led to an unfavourable economic situation in this region, due to which active persons of working age are forced to leave their homes and seek employment in larger centres.

\section{Conclusion}

Based on the presented data we can see that the percentage of unemployed persons in the total population in municipalities covered by the study is quite large, but that the situation in most of the border municipalities is relatively favourable, as the percentage of unemployed persons does not increase, but there is a trend of slight decline. Regretfully, many people decide willingly to get deleted from the Register of the National Employment Service because they believe that this institution cannot help them to find a job.

The data of the National Employment Service show that according to the age persons in the age group of 45-49 dominate in the structure of unemployed persons in municipalities of Novi Knezevac and Coka, while in the municipality of Kikinda very young and most active persons of working age 25-29 dominate. The smallest share in the total number of unemployed belongs to persons 60 and older, since majority of persons in that age group (especially women) have already fulfilled the conditions for retirement. There is also a small share of persons younger than 20 , because the majority of persons in this age group are still in included in the education process. The structure of unemployed persons according to the level of education shows that there is the highest percentage of people with education level I, followed by persons with levels III and IV. A positive fact is that the share of unemployed persons with higher levels of skills, i.e. levels from V to Vlll, is small in municipalities of Novi Knezevac and Coka, whereas it is not the case with the municipality of Kikinda that has a substantial share of those persons.

Halting of emigration process from the territories of the subject municipalities would contribute to stabilisation of their demographic status. The accomplishment of this objective will depend primarily on economic development, namely on possibilities to offer appropriate jobs to young, educated people. 
The problem of unemployment in the territories of border municipalities of Banat could be regulated primarily with elaboration of a longterm plan, and its implementation in several stages. Correct planning of all the activities at several different levels is very important. The implementation of plans should include the resident of local communities of all age groups.

There are several possibilities for revitalisation of areas affected by depopulation. Considering that a large percentage of people in border regions of Banat are involved in agriculture, improvement of the status of agriculture in general may be one of the solutions for this problem.

Absence of strong economy, in particular in rural communities, has to be replaced by appropriate and worthy alternatives. Being filled with history and tradition created by the work of numerous generations of men and women, rural regions provide the rich heritage as a strong cultural identity. The development of tourism and hospitality industry is a significant precondition for mitigating of unemployment problem in those regions.

Although the young and active persons constitute the priority, the elderly should also be included in the process so that they can also contribute to the development as far as their abilities allow. Good examples were noticed in Moscow, Japan as well as in many other West European countries, where a significant number of museums and galleries gave employment exclusively to the elderly (mainly women). Their job is to sit in the exhibition areas, guard the exhibited pieces against improper visitors and provide basic information upon the request of the visitors. This is an easy job which can also be adjusted to persons with minor invalidity. In this way the unemployment rate of persons over 50 years of age is reduced, which is at the same time the most difficult category to find employment.

Taking into account that the whole border region of Banat is multiethnic and that a large percentage of national minorities live in that region, good knowledge of native and languages of the community make one of the factors that can affect reduction of unemployment.

Special attention should be paid to possibilities of elaboration of several different employment schemes offered by the state within the National Employment Service.

\section{Acknowledgements}

The paper is a part of the Project (Contract of the project - EVB: II4-45I-02496/20IO-I, "Creating Programmes for the Revitalisation of Depopulated Border Regions in Banat", financed by the Provincial Secretariat for Science and Technological Development).

\section{References}

Boeri, T., Macis, M. 2009. Do unemployment benefits promote or hinder job reallocation? Journal of Development Economics (In Press, Corrected Proof, Available online).

Brown, A.J.G., Orszag, J.M., Snower, J.D. 2008. Unemployment accounts and employment incentives. European Journal of Political Economy 24, 3, 587-604.

Carling, K., Edin, P., Harkman, A., Holmlund, B. I996. Unemployment duration, unemployment benefits, and labor market programs in Sweden. Journal of Public Economics 59, 3, 313-334.

Chang, S.S., Sterne, A.C.J., Huang, C.W., Chuang, L.H., Gunnell, D. 20I0. Association of secular trends in unemployment with suicide in Taiwan, I959-2007: A time-series analysis. Public Health I24, I, 49-54.

Čvoro, J. I982. Geography of tertiary economic activities of Herzegovina - development laws and factors. Doktorska teza, Univerzitet u Novom Sadu, Prirodno-matematički fakultet.

Data of the National Employment Service Kikinda. 2009.

Dur, A.J.R. 20oI. Explaining unemployment trends in the Netherlands. Journal of Policy Modeling 23, 2, I6I-I68.

Đurđev, S. B., 2006. Challenges of depopulation. Zbornik Matice Srpske za društvene nauke I2I, III7.

Ezzy, D. I993. Unemployment and mental health: A critical review. Social Science \& Medicine 37, I, 4I-52.

Fergusson, D.M., Boden, J.M., Horwood,J.L. 2007. Unemployment and Suicidal Behavior in a New Zealand Birth Cohort: A Fixed Effects Regression Analysis. Crisis: The Journal of Crisis Intervention and Suicide Prevention 28, 2, 95-IOI.

Galiani, S., Hopenhayn, A.H. 2003. Duration and risk of unemployment in Argentina. Journal of Development Economics 7I,I, I99-2I2.

Gomes F.A.R, Gomes da Silva, C. 2009. Hysteresis versus NAIRU and convergence versus divergence: The behavior of regional unemployment rates in Brazil. The Quarterly Review of Economics and Finance 49, 2, 308-322.

Graetz, B. I993. Health consequences of employment and unemployment: Longitudinal evidence for young men and women. Social Science \& Medicine 36, 6, 715-724.

Hammarström, A. I994. Health consequences of youth unemployment-review from a gender perspective. Social Science \& Medicine 38, 5, 699709.

Ivkov, A., Bubalo-Živković, M., Lukić, T., Dragin, A., Ivanović, Lj., Pašić, M. 20Io. Demographic development of border municipalities in 
Banat in the second half of the $20^{\text {th }}$ century. Prirodno-matematički fakultet, Departman za geografiju, turizam i hotelijerstvo, Novi Sad.

Ivkov, A., Dragin, A., Kovačević, T., Đurđev, B., Ivanović, Lj. 2007. Influence of Tourism on the Employment in Vojvodina. Geographica Pannonica II, 54-58.

Kingdon G.,G., Knight, J. 2004. Unemployment in South Africa: The Nature of the Beast. World Development 32, 3, 39I-408.

Kingdon, G., Knight, J. 2006. The measurement of unemployment when unemployment is high. Labour Economics I3, 3, 29I-3I5.

Kivimäki, M., Elovainio, M., Kokko, K., Pulkkinen, L., Kortteinen, M., Tuomikoski, H. 2003. Hostility, unemployment and health status: testing three theoretical models. Social Science \& Medicine 56, I0, 2139-2I52.

Kupets, O. 2006. Determinants of unemployment duration in Ukraine. Journal of Comparative Economics 34, 2, 228-247.

Mijanović, D. 2008. Population of the mountainous hinterland of Niksic Municipality. Zbornik radova geografskog fakulteta 56, 73-80.

Mukoyama, T., Şahin, A. 2009. Why did the average duration of unemployment become so much longer? Journal of Monetary Economics 56, 2, 200-209.

Nevenić, M. 2009. Significance of Belgrade in socio-economic development of Serbia. Zbornik radova geografskog fakulteta 57, I23-I38.

Pašić, M., Ivkov-Džigurski, A., Dragin, A. 2010. Unemployment as one of the leading depopula- tion problems in border municipalities. Zbornik Matice Srpske za društvene nauke I3I, 279-292.

Pavlović, S., Jovanović, B. 2009. Complementarity of eco and ethno tourism on the examples of Zlatibor villages. Zbornik radova geografskog fakulteta 57, I65-180.

Platt, S., Micciolo, R., Tansella, M. I992. Suicide and unemployment in Italy: Description, analysis and interpretation of recent trends. Social Science \& Medicine 34, II, II9I-I2OI.

Statistical Office of the Republic of Serbia. 2004a. Opšti podaci, Opštine u Srbiji, Republika Srbija, Beograd, I5.

Statistical Office of the Republic of Serbia. 2004b. Popis domaćinstava i stanova u 2002. Stanovništvo. Delatnost pol. Knjiga 6. Beograd.

Statistical Office of the Republic of Serbia. 2004c. Popis stanovništva 2002. Uporedni pregled broja stanovika I948, I953, I96I, I97I, I98I, I99I i 2002. Podaci po naseljima. Beograd.

Van Ours, J.C., Vodopivec, M. 20o8. Does reducing unemployment insurance generosity reduce job match quality? Journal of Public Economics 92, 3-4, 684-695.

Vujadinović, S., Gajić, M. 2008. Limitations of demographic and spatial-functional development of Knic settlement. Zbornik radova geografskog fakulteta 56, 8I-94.

Vuksanović, G., Đurđev, S.B., Ivkov, A. 2004. The Province of Vojvodina in the Vicinity of EU Regions A General Comparison of Human Resources with the Emphasis on (Un)employment. Geographica Pannonica 8, 29-32. 